\title{
Selection of Russia Non-Resource Development Model
}

\author{
${ }^{* 1}$ Elena V. Bodrova, ${ }^{2}$ Viacheslav V. Kalinov, ${ }^{3}$ Valeriya N. Krasivskaya, ${ }^{4}$ Sergey V. Sergeev \\ 1,3 Moscow Technological University (MIREA), 19454, Moscow, Vernadsky Prospekt, 78 \\ ${ }^{2,4}$ Gubkin Russian State University of Oil and Gas (National Research University), 119991, Moscow, Leninsky \\ Prospect, 65, Building 1 \\ Email:*evbodrova@mail.ru
}

Received: 16 $^{\text {th }}$ May 2018, Accepted: $04^{\text {th }}$ June 2018, Published: $30^{\text {th }}$ June $_{2018}$

\begin{abstract}
On the basis of previously unpublished archival documents and materials we studied the problem of long-term struggle in the scientific, governmental and business circles of the Russian Empire related to the construction type of the Caspian-Black Sea pipeline, capable to transport crude or processed oil. The conclusion is drawn that the development strategy was determined as a matter of fact not only for the oil industry, but for the entire Russian economy. It was about the establishment of an own industrial production or crude oil export, its use as a source of immediate profit, providing oil producers and treasury. The result of the victory aimed on the national interests of a part of the governmental, entrepreneurial and scientific elite was the following one: the focus on the non-resource development model, the decision to build a kerosene pipeline and the growth of the oil refining industry in Russia.
\end{abstract}

Keywords: Modernization; Oil Industry; Economic Strategy

\section{Introduction}

The relevance of the problem selected for the study is determined by the inhibition of modernization processes in Russia, the reason of which is an inefficient commodity model of economic development in many respects. The experience of the country integration in the global economy during 90ies as the result of liberal reforms have resulted in the destruction of the processing industry within its high technology aspect, the growth of "commodity" industries and the industries with energy- and water capacities and toxic emissions [1]. Meanwhile, a significant part of the leading scientists called for a change in this strategy during many years, suggested that a large share of the proceeds from commodity exports is directed to the Russian economy development as a whole, primarily its high-tech sectors. So, on November 24, 2011 the Academician A.E. Kantorovich spoke at the parliamentary hearings of RF Federal Assembly at the State Duma. He was convinced that the availability of raw materials is not a stigma, not a misfortune. "Why does the US is not characterized as a commodity power, producing slightly less amount of oil and an equal amount of gas, $85 \%$ of the world helium, 3.5 times more coal than Russia? - he wondered. - It's not just how much minerals we extracted, the thing is in the way of their use" [2].

The historical experience of national project implementation and the involvement of the scientific community to the development of the state scientifictechnical and socio-economic policy conceptual bases is extremely valuable in modern Russia, as it allows you to learn, to accumulate all effective and to realize fully the specifics of Russian modernization model. However, the researchers studied this problem poorly.

\section{Materials and Methods}

It seems possible to distinguish three main stages of the problem scientific discussion: in the historical works of the XIXth - early XXth centuries; in the monographic studies of the Soviet period; in the publications during the 90-ies of the XXth - early XXIst centuries. In the studies of the pre-revolutionary stage, along with the analysis of the wide discussion that developed in the periodicals about the expediency of the Caspian-Black Sea pipeline construction, the authors also emphasized an active opposition to almost all such projects on the part of Baku oil refineries [3]. K.I. Lisenko [4], I.N. Glushkov [5] and others wrote on the nature of the discussions that were conducted on this issue in the Imperial Russian Technical Society during that period.

The works of the Soviet period were distinguished by a high qualification level, the introduction of a wide range of sources and concepts and a rich factual material into circulation. However, the reliance on official ideological guidelines significantly narrowed the range of issues under consideration, predetermined the formulation of conclusions and recommendations in these papers [6-10]. The work, published during the Soviet period, was the work by S.M. Lisichkin "Outstanding figures of Russian petroleum science and technology", deserved the attention, in which the author supported D.M. Mendeleyev's position on the construction of an oil pipeline and categorically condemned the "false fabrications of corrupt foreign 
journalists" [11], who "made an organized noise" in 1889 about the depletion of Baku oil fields in order to disrupt the construction of an oil pipeline from Baku to Batum.

The modern stage of the domestic historiography of the problem is characterized by the authors' attempt to make broader analytical generalizations, to use various theoretical and methodological approaches. A number of works appeared, in which the issues were considered that had not attracted the attention of historians previously. We rightly refer the monograph by I.A. Dyakonova "Oil and coal in the energy of tsarist Russia in international comparisons" to such studies. The author has carried out the analysis of a very peculiar energy structure of pre-revolutionary Russia from the point of view of the place of Russia in world industrial development [12]. The articles of modern authors A.M. Shammazov, B.N. Mastobayev, A.E. Soschenko [13], V.I. Shulyatikov [14] and A. Troshin [15] only mention the studied problem among other ones, some of its aspects are indicated. In order to study the topic, the works of the well-known researchers A.A. Matveychuk and T.A. Bagirov concerning oil industry development history within Russian industry are of undoubted value. These works contain the information regarding the participation of Nobels in the determination of pipeline construction type [16]. However, a number of significant subjects concerning the problem under study needs to be rethought. Our article is an attempt to fill this gap.

The source base for this article were the documents studied by us, which are stored in the funds of the Russian State Historical Archive. The documents of the Mining Department, which was under the jurisdiction of the Ministry of State Property from January 1, 1874 to March 21, 1894, from March 21, 1894 to May 7, 1905 - the Ministry of Agriculture and State Property, from May 7, 1905 to October 27, 1905 - the Ministry of Finance, from October 27, 1905 to October 26, 1917 - the Ministry of Trade and Industry [17]. The reports and the letters of the Salt section of the Mining Department was of particular importance for the problem study, as it, among other things, was in charge of matters related to the discovery and the development of oil sources. The correspondence between the heads of various departments, the reports on the results of the special commission work make it possible to study the evolution of state policy thoroughly and objectively concerning not only the construction of the Caspian-Black Sea pipeline, but also the choice of an economic strategy. The publications and the letters by D.I. Mendeleyev, I.P. Ilimov concerning the prospects for the development of oil industry, as well as the works of the Imperial Russian Technical Society were of a great value for us. The article adopts the modernization theory as a basic one, which assumes the analysis of the processes taking place in the world, from the point of view of the transition from the agrarian society to the industrial one, and in a broader sense - the consideration of all phenomena through the prism of modernization. The specificity of the Russian model of modernization is the overtaking, military-political, largely "borrowing" character, which determined the special role of the state in its forcing, the progressive centralization and the bureaucratization of social and economic process management.

The multidimensionality of the studied processes required the involvement of both general scientific methods of research (logical, structural-functional, classification and systematization), and special historical (historical-comparative, historicalretrospective, historical-genetic, etc.).

\section{Results}

The significance of the problem we study is determined by the fact that the state policy of the Russian Empire in the oil sector has largely determined the nature and the pace of industry development, the stages of its evolution and the course of industrialization as a whole. It evolved from the proclamation of the "mountain freedom principle" in the production of prospects (1872-1884) to the prohibition of private entrepreneurial exploration activities on state lands in the Baku region because of the threat to lose control over the most promising part of the state-owned lands. The factor that determined the strengthening of the state role was the accelerated industrial development during the post-reform period, the expansion of oil use scale as an energy carrier.

Due to the energetic measures of the government, the abolition of the "payoff system," during the decade of 1873-1883 the oil production in Baku increased from 4 to 60 million poods, that is, in 15 times [18]. The increase of oil production was due to a radical change of oil fields development, the expansion of their total area, labor productivity and the number of oil companies increase (by 1878 , their number reached 112) [19], the improvements in production technology. The production of kerosene has grown rapidly in the second half of the 1870-ies. Since 1881, the export of kerosene began, and its import completely ceased already in 1882 . According to a fair assessment by I.A. Dyakonova, Russian entrepreneurs were able to apply an unused trump card in the competitive game with the US - the transfer of Russian oil fields from semi-feudal to capitalist races [20]. After the excise duty was abolished in 1877 , the prices for kerosene and other petroleum products dropped significantly, the oil refining industry began to grow at an accelerated pace.

The construction of oil pipelines has become a 
milestone in the development of the industry. D.I. Mendeleev proposed this idea in 1863 during his work at Kokorev's Surakhani plant. He regarded the use of pipelines for oil and oil product pumping as the first condition for domestic oil industry prosperity. However, Baku authorities resisted the construction of a pipeline, fearing the speeches of the hoopers and donkey drivers, who were deprived of work in this case. Meanwhile, such an archaic transportation cost dearly, it stopped in bad weather. The partnership of the oil production by Nobel brothers appealed to all major oil producers with the proposal to build an oil pipeline, but they were misunderstood and they decided to start construction at their own expense [21]. The pipes for the pipeline were bought in America, because they were out of competition due to their quality, low price and fast delivery. The pipes were buried at the depth of two meters, Cossacks were sent to guard the entire route from the fields to the port [22]. But the building warehouses were set on fire, the pipes were damaged [23]. Nevertheless, in 1878 A.V. Bari and V.G. Shukhov built an oil pipeline in the vicinity of Baku for "Br. Nobel" company (Balakhany - Black City). It was the first commercial oil pipeline in Russia.

A major contribution to the development of oil pipeline transport was made by S.G. Voislav, K.I. Lisenko, L.S. Leibenzon, M.I. Lazarev, I.P. Ilimov and many other Russian scientists, engineers and inventors. The first oil pipelines have proved their high profitability as the type of oil transport, predicted by D.I. Mendeleev [24]. The costs of their construction, as a rule, paid off during the first year of operation, so the pipeline transport was used actively.

On the turn of 1887-1888, the Russian oil industry focused more and more on the export of kerosene, competing with the Rockefeller corporation in the European kerosene markets. However, the transportation of Caucasian oil and oil products to the ports of the Black Sea for their export to the world market remained a difficult problem. In 1882 A.A. Letny characterized this issue at the meeting of the Imperial Russian Technical Society as the main condition for a successful competition with the Americans in the report devoted to the measures of Caucasian oil transportation development and cost reduction to the southern ports along the Transcaucasian railway, which was more profitable than by the district route along the South Russian roads. This has actualized the need to build trunk pipelines [25]. The opponents of this project, in their turn, proved the profitability of rail transport for the transportation of oil products, expressed the concern about a possible very rapid depletion of resources. D.I. Mendeleyev answered them that there would be enough oil for everyone in the Caucasus, "... from experience, both American and Baku, it is known that a pipeline maintenance is more than twice cheaper than a railroad with the same amount of products" [26]. A. Rothschild, G.Z. Tagiev, I.P. Ilimov, Musa Nagiyev, A.M. Benckendorf, S.I. Bagirov and others were among the industrialists who supported the idea of an oil pipeline building.

Previously unpublished documents that are kept at the Russian State Historical Archive (RSHA) in St. Petersburg allow us to understand the depth of the disagreements and the significance of the decision that was finally made.

Initially, the issue of a concession for the construction of the Caspian-Black Sea oil pipeline was solved, which the US citizen G. Tvedel and the Moscow plant owner G. List, and the retired Lieutenant-Captain A.P. Khanykov, and the Paris Banking House of Rothschilds planned to receive. Very unclear conditions and prospects offered by the applicants prompted the Minister of State Property M.N. Ostrovsky to warn the Minister of Finance, emphasizing all the advantages of the pipeline in a message addressed to him in January 1884: "It is necessary to regard the construction of an oil pipeline extremely cautiously ... The concession can be issued only after a comprehensive discussion of all the conditions which oil production has currently" [27]. The projects of Tvedel and Khanykov were characterized by him very negatively: "... they differ by complete uncertainty both technically and economically ... are limited by the indication of rights and benefits that concessionaires should use" [28]. M.N. Ostrovsky offered to postpone "until the Ministry of State Property clarifies fully the current situation of the oil industry" [29]. To this end, a special commission was set up to draw up an expert opinion of the Mining Department, headed by the actual state councilor Tikheev [30]. Moreover, the Minister visited the Balakhano-Sabunchinsky district personally and was convinced that the operation of wells was absolutely wasteful and "the supply of raw materials exceeded demand for it, it was not sold even at extremely low prices", "oil is wasted uselessly and irretrievably" [31]. At the same time, he was forced to state in his report that "the dispatch of processed oil products towards Batum was in a very imperfect state" [32]. Therefore, the Ministry of State Property considered it is necessary to point to a pipeline as a "convenient and cheap transportation means to the shores of the Black Sea", capable to deliver 20 million poods of kerosene additionally [33]. At the same time, the experts of the Mining Department insisted on the need to build new oil refineries in Baku, which could modernize production under competitive conditions, thereby reducing the price and improving the quality of processing [34]. 
The issue of a pipeline construction was submitted for discussion at the First Congress of Oil Producers, which was held in Baku in 1884, but was postponed indefinitely [35].

Meanwhile, V.G. Shukhov developed the scheme and the estimate of the Baku-Batumi oil pipeline, the main parameters of the project were published in the October issue of "Industry Bulletin" in 1884. The actual state councilor, the doctor of technology I.P. Arkhipov, who was on service at the Ministry of State Property during that period Arkhipov, published an article in the same issue entitled "The Measures Proposed by the Ministry of State Property for the Development of Russian Oil Industry," in which it was argued that it would be more profitable to transport oil to Batumi and refine it there [36]. A strong supporter of such a solution was a chemist, a businessman, a honorary member of the Russian Physical and Chemical Society I.P. Ilimov. He believed that Baku can not be developed successfully as a center of oil refining because of the unfavorable climate, the lack of fresh water, the remoteness from industrial, first of all, machine-building enterprises and the markets for oil products [37]. In order to build an oil pipeline from Baku to Batum, he established the company together with retired Major-General A.S. Lavrov and soon received a concession [38].

However, the construction of the Baku-Batumi oil pipeline meant that conditions would thus be created for large-scale export of crude Russian oil abroad. This was the reason for a broad discussion in the scientific and business community during the second half of the 80-ies of the XIXth century. Oil producers and scientists were not united, some of them favored the construction of a kerosene pipeline, the development of an own oil refining. In order to promote Russian industry and trade in February 1886, D.I. Mendeleyev, G.Z. Tagiev, I.P. Ilimov, M.I. Lazarev, V.I. Ragozin, L.E. Nobel and other supporters and opponents of raw materials and oil product sale abroad presented their reports.

According to D.I. Mendeleev, it was necessary to build the Caspian-Black Sea oil pipeline, but not a kerosene pipeline. On March 15, 1887, the scientist wrote: "... all our existing counteractions to the Transcaucasian oil pipeline are based not on any patriotic or even local Baku interest, but on the narrowness of personal calculations and opinions, or on the pressure and the motivation of an able, a large and a sensitive American oil industry. An oil pipeline is the first and only readily available means for the development of the Caucasian oil business" [39]. Moreover, the scientist believed, that an oil pipeline should be built not by the treasury, but by private capital via the provision of a controlled concession for a pipeline construction and use [40].

In 1887, the struggle over the issue of the
Transcaucasian oil pipeline continued. By this year, A. Rothschild actually monopolized the oil transportation by rail, delayed the dispatch of goods in order to ruin the rivals. The next step was to build a powerful oil pipeline from Baku to Batum. According to a number of researchers, it was Rothschild who inspired the newspaper campaign to support an oil pipeline construction [41]. Moreover, Rothschild managed to find support from a number of Russian officials of the highest rank. The actual secret adviser A.A. Abaza, for example, believed that the construction of the Caspian-Black Sea oil pipeline is possible at the expense of the treasury [42]. On February 28, 1887, the Ministry of State Property entered the Committee of Ministers with the presentation on the organization of a pipeline by private entrepreneurs. In its turn, the Committee of Ministers granted the right to the Ministry of State Property to make a competition, in agreement with the Ministry of Finance, between the persons who expressed a desire to take over the formation of a joint stock company for the construction and operation of this pipeline on April 8 of the same year. I.P. Ilimov received the concession, the right to which was conditioned by his obligation to contribute $40 \%$ to the treasury from all shares and a pledge of one million rubles [43]. However, referring to the "Rothschild's firm counteraction", he asked the government to extend the term of deposit. But the activity of Ilimov's opponents inside the country and the unfavorable conditions of fund provision by the "British capitalists" forced the government to abandon such an option [44]. Therefore, the issue of building an oil pipeline at the expense of the treasury was raised again. An estimate was drawn up, which assumes the allocation of 24.5 million rubles for 4 years [45].

L. Nobel was one of those who sharply opposed the construction of a pipeline. He gave a negative assessment and also proposed to lay a kerosene pipeline from Baku to Batum, instead of crude oil product supplying the products with high added value to international markets in the letter to the Minister of State Property M. Ostrovsky on March 13, 1887 [46]. But the idea of an oil pipeline was not rejected. On April 20, 1887, it was decided to provide the Minister of State Property a discussion together with the representatives of various ministries concerning the issue of a port selection - Batumi or Poti - during the construction of the Caspian-Black Sea oil pipeline [47; 48]. The condition of the Poti port was such that Batumi was given the advantage [49]. The interests of the Maritime Department also demanded the construction of an oil pipeline towards Batumi [50]. In November 1887, the Minister of State Property M.N. Ostrovsky submitted a draft charter for a future oil pipeline company to the Committee of Ministers. According to the plan of the Ministry and the 
paragraph 17 of the Charter, the Rothschild company could obtain the right to duty-free export of oil residues for a period of 60 years. In such a situation, L. Nobel and S. Shibaev applied to the Emperor Alexander III personally. This position was supported by the Imperial Society for the promotion of Russian merchant shipping, which became a kind of center that united the opponents of crude oil exports. Its general meeting on December 12, 1888 decided unanimously to intercede immediately on unconditional prohibition of raw material export, all sorts of refuse from oil production and semi-processed products; on the authorization of the free export only finished goods coming directly to a consumer, and not to the factories for finishing; to prevent Ilimov from granting a further postponement after January 12, 1889 for the creation of the stock capital for Caspian-Black Sea oil pipeline Company [51].

\section{Discussion}

The archival documents studied by us made it possible to broaden the understanding of discussion course at the turn of the 1880s-90s related to the construction of the Caspian-Black Sea oil pipeline. The views on the pipeline construction were diametrically opposed. All the main conceptual approaches were seriously criticized by the most authoritative representatives of science and industry. Agreeing, in particular, with the assertions that the production technology on the Apsheron peninsula is not perfect, while the opponents of the pipeline construction did not see it as the only incentive for the technical re-equipment of production, it was considered possible to use other means for this purpose. They considered it was not necessary to increase prices artificially. A cheaper and more affordable delivery of crude oil to the maritime boundary would help to compete more successfully in European markets, but it would have a negative impact on the development of domestic production and its modernization, according to the right assertion of this position supporters.

On March 3, 1890, the Committee of Ministers decided: "Without prejudging the issue concerning the preference among 2 types of oil product transfer from Baku to the Black Sea ports (an oil pipeline or a kerosene pipeline) one should recognize that this structure is a state enterprise intended for general use, and it must be arranged by treasury means and operated by the order of the Government, with the decline of such a pipeline construction by a private company" [52]. At the same time, it was decided to establish a commission which must decide on a pipeline type selection. The commission consisted of the Ministry of Railways and state property representatives. The experts of the Commission made very detailed calculations of a pipeline building cost between Baku and Batumi to pump 60 million poods of oil per year. The cost of a kerosene pipeline construction was two times less than the amount planned for the construction of an oil pipeline. The operation would also have been cheaper [53]. However, the leadership of the Ministry of State Property questioned the advantages of a kerosene pipeline, since it would be necessary to increase its production for oil refining, which could lead to a crisis, and, consequently, to treasury losses: "A kerosene pipeline will only increase the demand for these riches, but will not contribute to their appearance on the market ... Sooner or later, there will be a lack of oil" [54]; "The extractive industry is the basis of all industry in general" [55].

However, the Ministry of Finance insisted that the productivity of oil refineries in Baku is high, oil refining should be developed in every possible way and, therefore, it is necessary to build a kerosene pipeline. The Ministry of Railways maintained the same position, pointing to a lower amount calculated for the construction of a kerosene pipeline. The Commission met on May 18, June 1 and November 1, 1890. Between these meetings the secret counselor P.P. Arkhipov and the actual State Councilor S.Yu. Witte visited Baku and studied the state of affairs in the Baku oil industry. But departmental disagreements proved to be insurmountable. Having examined "the benefits and the disadvantages" associated with an oil pipeline or a kerosene pipeline construction, having familiarized with the calculations of experts and the positions of various departments, the Commission reached a unanimous conclusion: "... With the current situation of the Apsheron production field and the Baku oil refining industry, neither an oil pipeline, nor a kerosene pipeline should be constructed via treasury means" [56]. Thus, in 1891 the Committee of Ministers postponed the construction of an oil pipeline as premature one [57].

Meanwhile, a powerful increase of oil production required an immediate solution of the transportation problem. The Council of oil producer congresses tried to draw the attention of government circles to the need of a kerosene pipeline construction in the summer of 1895 , but this appeal remained unanswered [58]. The final decision on the construction accelerated the flood in October 1895, which destroyed many railway facilities on the pass section of the South Caucasus Railway. On December 10, 1895 the Chairman of oil producer congress Council P.O. Gukasov sent a telegram to the Minister of Finance I.A. Vyshnegradsky, which described the disastrous condition of the railway track after the flooding and noted the impossibility of its soon recovery. "The losses that the treasury and all the oil owners suffer are incalculable," the telegram said. - In view of the 
foregoing ... The Council of the Congress convincingly requests your Excellency for an immediate construction of the 8-inch kerosene pipeline by the means of the treasury from the Mikhailovo station to the Ajameta station, which is highly desirable to continue to Batum then at the urgent request of all oil owners of the Baku region" [59]. Only on May 23, 1896, it was finally decided to construct the Baku-Batum trunk oil pipeline, which became the largest infrastructure facility of prerevolutionary Russia in the beginning of the 20th century [60].

The construction of Baku-Batum trunk pipeline, laid along the line of the Transcaucasian railway, was started in 1897 and lasted for ten years. The final design of the structure, calculated by G.K. Merching, was developed by a prominent expert in the field of locomotive and car building Professor N.L. Shchukin [61]. It was the longest ( $885 \mathrm{~km})$ kerosene pipeline, its annual throughput was 60 million poods. All the pipeline facilities were built at a high technical level for that time, and the pipeline itself was one of the most powerful in the world.

\section{Conclusion}

Thus, the construction of the Caspian-Black Sea pipeline in the second half of the nineteenth century was not only a large-scale technical project. It was about the priority for Russia: the development of its own industrial production or the export of crude oil and the receipt of immediate profits that went into the pocket of oil producers and the treasury. The perseverance of scientists, entrepreneurs and a number of government officials ensured the technical reequipment of the oil industry, and the qualitative growth of oil refining. This decision was a frontier in the history of the Russian oil industry. By the end of 1914 , the total length of oil and product pipelines in Russia was $1,278.7 \mathrm{~km}$ and $14,000 \mathrm{~km}$ in the USA, including $7,000 \mathrm{~km}$ of trunk lines. The level of technical equipment was approximately the same. The construction of the kerosene pipeline allowed to preserve the former structure of oil exports: in 1913, crude oil accounted for only $0.05 \%$ of oil export cost, and $6.8 \%$ for fuel oil [62]. The modernization of the oil industry played a significant role in the transformation of Russia from a backward agrarian country to an agrarian-industrial power in the beginning of the XXth century.

\section{References}

[1] Sukhorukova S.M., Pogorely A.M., Samorokov A.V. The influence of the international technological division of labor on environmental and industrial security // The Russian Technological Journal. 2016.
Vol. 4, No. 4 (13). pp. 73-74.

[2] State Duma archive of RF Federal Assembly. F. 10100. Inv. 196p-5. C. 92. Sh. 72

[3] Lazarev M.I. The current situation of Russian oil industry and oil exports. St. Petersburg, 1889. $142 \mathrm{p}$.

[4] Lisenko K.I. Oil production, described according to the latest data by K. Lisenko, the Professor of the Mining Institute and the Chairman of the I-st Division of the Imperial Russian Technical Society. St. Petersburg, $1878.282 \mathrm{p}$.

[5] Glushkov I.N. Historical outline of BO IRTO activity // Proceedings of the Baku branch of the Imperial Russian Technical Society. 1905. Issue 5. May-August.

[6] Kokh M.A., Ol P.V. Oil industry. M., 1925. $67 \mathrm{p}$.

[7] Kreynin G.S., Rubinshtein Ya.E. The economy of oil. Essays. M.; L., 1930. 179 p.

[8] Frolov V.I. Economics of the oil eindustry. M., 1928. 392 p.

[9] Eventov L.Ya. Foreign capital in Russian industry. M.; L., 1931. 103 p.

[10] Lisichkin S.M. Essays on the history of domestic oil industry development. Prerevolutionary period. M.; L., 1954. 401 p.

[11] Lisichkin S.M. Outstanding figures of Russian petroleum science and technology. M., 1967. p. 74

[12] Dyakonova I.A. Oil and coal in the power industry of tsarist Russia in international comparisons. Moscow: ROSPEN, 1999. 296 p.

[13] Shammazov A.M., Mastobaev B.N., Soschenko A.E. Pipeline transport of Russia (1860-1917) // Pipeline oil transport. 2000. № 6. 2000. № 6. URL: http://www.tnpro.ru/index.php/article/history/1413--18601917, free access (reference date: 07.04.2018).

[14] Shulyatikov V.I. Oil exports was prohibited in the empire. URL: http://www.morvesti.ru/tems/detail.php?ID= 55066 free access (reference date: 07.07.2016).

[15] Troshin A. The first main Russian pipeline // At oil crossroads: the collection of historical essays. M.: "Ancient Storage", 2004. pp. 4048.

[16] Matveychuk A.A. Bagirov T.A. Oil crossroads of the Nobel brothers: Historical essays. M., 2004. 434 p.

[17] Russian State Historical Archive (hereinafter - RSHA). F. 37. Historical background.

[18] The Caucasian calendar for 1885. Tiflis. 
1884, Department III. p. 276.

[19] Koh M.A., Ol P.V. Oil industry. M., 1925. p.9.

[20] Dyakonova I.A. Oil and coal in the power industry of tsarist Russia in international comparisons. Moscow: ROSPEN, 1999. p. 50

[21] Thirty years of Nobel Brothers Oil Production Association activity. 1879-1909. St. Petersburg, 1914. p. 87

[22] Osbryn B. Empire of Nobels: a story about the famous Swedes, Baku oil and the revolution in Russia / trans. from Swed. by T. Dobronitskaya. M., 2003. p. 35

[23] Thirty years of Nobel Brothers Oil Production Association activity. 1879-1909. St. Petersburg, 1914. p. 87.

[24] Mendeleev D.I. The Baku oil business in 1886. SPb.: Type B. Demakova, 1886. p. 100

[25] Shammazov A.M., Mastobaev B.N., Soschenko A.E. Pipeline transport of Russia (1860-1917) // Pipeline oil transport. 2000. № 6. 2000. № 6. URL: http://www.tnpro.ru/index.php/article/history/1413--18601917, free access (reference date: 07.04.2018).

[26] Mendeleev D.I. On oil affairs // Works. L.; M.: Publishing house of the USSR Academy of Sciences, 1949. V. 10. Oil. pp. 501-502.

[27] RSHA. F. 37. Inv. 31. C. 483. Sh. 10 overleaf.

[28]RSHA. F. 37. Inv. 31. C. 483. Sh. 10 overleaf.

[29] RSHA. F. 37. Inv. 31. C. 483. Sh. 11.

[30]RSHA. F. 37. Inv. 31. C. 483. Sh. 19.

[31] RSHA. F. 37. Inv. 31. C. 483. Sh. 33.

[32] RSHA. F. 37. Inv. 31. C. 483. Sh. 33 overleaf.

[33] RSHA. F. 37. Inv. 31. C. 483. Sh.34-35.

[34] RSHA. F. 37. Inv. 31. C. 483. Sh. 35.

[35] Matveichuk A.A., Bagirov T.A. Oil crossroads of the Nobel brothers: Historical essays. M., 2004. pp. 62-63

[36] Shammazov A.M., Mastobaev B.N., Soschenko A.E. Pipeline transport of Russia (1860-1917) // Pipeline transport of oil. 2000. № 6. 2000. № 6. URL: http://www.tnpro.ru/index.php/article/history/1413-1860-

1917, free access (reference date: 07.04.2018).

[37] Ilimov I.P. Oil pipeline and oil industry in Baku. St. Petersburg, 1884. 48 p.

[38] Ilimov Ivan Petrovich. URL: http:/dic.academic.ru/dic.nsf/enc_biography /45552/Илимов, free access (reference date: 21.02.2018).

[39] Mendeleev D.I. On the issue of an oil pipeline and a kerosene pipeline // Works. L.; Moscow: Publishing House of the USSR Academy of Sciences, 1949. V. 10. p. 736

[40] Mendeleev D.I. On the issue of the oil pipeline and kerosene pipeline // Works. L.; Moscow: Publishing House of the USSR Academy of Sciences, 1949. V. 10. pp. 740741.

[41] Shulyatikov V.I. Oil export was prohibited in the empire. URL: http://www.morvesti.ru/tems/detail.php?ID= 55066, free access (reference date: 07.07.2016).

[42] RSHA F. 37. Inv. 31. C. 439. Sh. 2

[43] RSHA F. 37. Inv. 31. C. 439. Sh.10-11 overleaf.

[44] RSHA F. 37. Inv. 31. C. 439. Sh. 11 об., 15 overleaf.

[45] RSHA F. 37. Inv. 31. C. 439. Sh. 16, 22.

[46] Трошин A. Первый магистральный российский трубопровод // На нефтяных перекрестках: сборник исторических очерков. М.: «Древнехранилище», 2004. C. 43.

[47]RSHA F. 37. Inv. 31. C. 409. Sh. 44 overleaf.

[48] RSHA F. 37. Inv.3. C. 395.

[49] RSHA F. 37. Inv. 31. C. 409. Sh. 9.

[50] RSHA F. 37. Inv. 31. C. 409. Sh. 9 overleaf 10.

[51] Shulyatikov V.I. Oil exports was prohibited in the empire. URL: http://www.morvesti.ru/tems/detail.php?ID= 55066, free access (reference date: 07.07.2016).

[52] RSHA F. 38. Inv. 31. C. 468. Sh. 75

[53] RSHA F. 38. Inv. 31. C. 468. Sh. 5-21.

[54] RSHA F. 38. Inv. 31. C. 468. Sh.38, 42, 43 overleaf

[55] RSHA F. 38. Inv. 31. C. 468. Sh. 76.

[56] RSHA F. 38. Inv. 31. C. 468. Sh. 88 overleaf.

[57] Ilimov Ivan Petrovich. URL: http://dic.academic.ru/dic.nsf/enc_biography /45552/Илимов, free access (reference date: 21.02.2018).

[58] Jalilov A.G. The construction of the BakuBatumi kerosene pipeline and the economy of the South Caucasus during the early twentieth century. URL: http://static.bsu.az/w8/Xeberler\%20Jurnali/ Humanitar\%20\%20\%202014\%20\%203/12 \%20\%20\%20\%20А.Г.Джалилов.pdf, free access (reference date: 22.03.2016).

[59] Report on the activities of the council elected at the 9th Congress of Oil Industrialists. Baku: The Council of the Oil Industry 
Helix Vol. 8(4): 3515- 3522

Congress. 1896. p. 85

[60] Troshin A. The first main Russian pipeline // At oil crossroads: a collection of historical essays. M.: "Ancient Repository", 2004. p. 43.

[61] Shchukin Nikolay Leonidovich. URL: https://docviewer.yandex.ru/?url=http $\% 3 \mathrm{~A}$ $\% 2 \mathrm{~F} \% 2 \mathrm{Flibrary}$.pgups.ru\%2Fjirbis $2 \% 2 \mathrm{Fima}$ ges $\% 2$ Fshchukin.docx\&name $=$ shchukin.doc $\mathrm{x} \&$ lang $=\mathrm{ru} \& \mathrm{c}=56 \mathrm{~d} 3559656 \mathrm{be}$, free access (reference date: 10.03.2018).

[62] Shammazov A.M., Mastobaev B.N., Soschenko A.E. Pipeline transport of Russia (1860-1917) // Pipeline transportation of oil. 2000. № 6. URL: http://www.tnpro.ru/index.php/article/history/1413-1860-

1917, free access (reference date: 07.04.2018). 